\title{
PENGARUH BERBAGAI MACAM MIKROORGANISME LOKAL (MOL) TERHADAP PERTUMBUHAN TANAMAN TOMAT (Lycopersicum esculentum Mill) VARIETAS PERMATA PADA TANAH ULTISOL
}

\author{
Effi Yudiawati, Eva Kurniawati \\ Program Studi Agroteknologi Fakultas Pertanian \\ Universitas Muara Bungo \\ email : effiyudia@yahoo.com \\ Naskah Diterima Agustus 2018, disetujui Maret 2019
}

\begin{abstract}
ABSTRAK
Penelitian ini bertujuan untuk mengetahui pengaruh berbagai macam Mikroorganisme Lokal (MOL) terhadap pertumbuhan tanaman tomat (Lycopersicum esculentum Mill). Penelitian ini menggunakan Rancangan Acak Lengkap (RAL) yang terdiri dari 4 perlakuan dan 4 ulangan. Adapun perlakuannya yaitu : M0 (Tanpa pemberian MOL), M1 (MOL Buah-buahan), M2 (MOL Bonggol pisang), dan M3 (MOL Sayur-sayuran). Variabel yang diamati adalah Tinggi Tanaman, Diameter Batang, Jumlah Daun, Umur Berbunga, dan Umur Panen Pertama. Variabel penelitian dianalisis secara statistik dengan Analisis Ragam dan Apabila berpengaruh nyata dilakukan uji lanjut dengan uji Duncan New Multiple Range Test (DNMRT) pada taraf 5\%.

Hasil penelitian menunjukkan bahwa berbagai macam MOL berbeda nyata terhadap tinggi tanaman $(\mathrm{cm})$, jumlah daun (Helai), dan umur panen pertama (hari) serta tidak berbeda nyata terhadap diameter batang $(\mathrm{cm})$, dan umur mulai berbunga (hari). Perlakuan M2 (Mol bonggol pisang) merupakan perlakuan terbaik untuk meningkatkan pertumbuhan tanaman tomat (Lycopersicum esculentum Mill) pada tanah ultisol.
\end{abstract}

\section{Kata Kunci : Tanaman Tomat, MOL, Pertumbuhan dan Hasil}

\section{PENDAHULUAN}

Tomat (Lycopersicum esculentum Mill) merupakan jenis tanaman sayursayuran berbentuk buah yang mempunyai rasa enak untuk dikomsumsi, baik berupa buah segar, maupun saos. Tomat memiliki segudang keunggulan. Rasa buahnya yang asam manis seakan memberikan kesegaran pada tubuh. Tomat memiliki kandungan vitamin dan mineral yang berguna untuk pertumbuhan dan kesehatan. Tomat juga mengandung zat pembangun jaringan tubuh dan zat yang menghasilkan energi untuk bergerak dan berfikir, antara lain karbohidrat, protein, vitamin, lemak dan kalori (Supriyati dan Siregar, 2009).

Buah tomat saat ini merupakan salah satu komoditas hortikultura yang bernilai ekonomi tinggi seiring dengan bertambahnya penduduk dan semakin berkembangnya usaha-usaha restoran, hotel dan swalayan yang membutuhkan suplai produk sayur-sayuran dan buah-buahan berkualitas tinggi dalam jumlah besar, maka perlu dilakukan usaha peningkatan produksi 
sayur dan buah-buahan baik secara intensif maupun extensif (Suprapto, 2000). Apabila dilihat dari rata-rata produksi tanaman tomat di provinsi Jambi tahun 2014 dengan luas panen 1.254 ha, dihasilkan produksi 14.729 ton, dengan produktivitas sebesar 11,75 ton/ha (BPS Jambi, 2014).

Salah satu faktor penyebab rendahnya produksi tomat yaitu rendahnya kesuburan tanah serta pemeliharaan yang masih belum optimal seperti penggunaan pupuk, pengendalian hama dan penyakit, dan lainlain. Sementara sebagian besar lahan di Provinsi Jambi didominasi oleh tanah ultisol dengan luasnya sekitar 2.272.725 hektar atau 42,53 \% dari 5.100.000 hektar luas wilayah Propinsi Jambi. Menurut Prahastuti (2005) kendala utama yang dijumpai didalam kaitannya dengan pengembangan Ultisol untuk lahan pertanian terutama karena termasuk tanah yang mempunyai harkat keharaan yang rendah. Selain hal tersebut di atas yang paling menjadi kendala dalam pengelolaan tanah ultisol adalah kandungan bahan organiknya yang sangat rendah yaitu kurang dari $2 \%$. Bahan organik tanah menyusun sekitar $5 \%$ bobot total tanah, meskipun hanya sedikit tetapi memegang peranan penting dalam menentukan kesuburan suatu tanah, baik secara fisik, kimiawi maupun secara biologis (Hanafiah, 2005).

Oleh karena itu perlu dilakukan usahausaha yang mengarah pada perbaikan tanah ultisol, salah satunya adalah dengan pemberian bahan organik diantaranya larutan Mikroorganisme Lokal (MOL). MOL merupakan larutan cair yang terbuat dari bahan-bahan limbah berperan dalam menjaga kesuburan tanah agar tanah sesuai bagi pertumbuhan tanaman. MOL dapat memperbaiki kondisi tanah, membantu pertumbuhan tanaman, meningkatkan ketahanan akar tanaman, pada daun dan batang akan mempengaruhi proses fotosintesis, menghancurkan dan mendekomposisi bahan organik dalam tanah, menguraikan senyawa organik kompleks, mol bisa juga menghasilkan zat yang berguna bagi tanaman seperti antibiotika, enzim dan asam laktat yang menekan pertumbuhan penyakit (Purwasasmita, 2009b).

Larutan MOL merupakan larutan hasil fermentasi yang berbahan dasar dari berbagai sumber daya yang tersedia di alam seperti bonggol pisang, maja, lamtoro dll. Larutan MOL mengandung unsur hara makro (N, P, K, Ca, Mg, dan S) dan mikro ( $\mathrm{Zn}, \mathrm{Cu}, \mathrm{Mo}, \mathrm{Co}, \mathrm{B}, \mathrm{Mn}$, dan Fe) dan juga mengandung bakteri yang berpotensi sebagai perombak bahan organik, perangsang pertumbuhan, dan sebagai agen pengendali hama dan penyakit tanaman (Syaifudin, Mulyani, dan Sulastri, 2010). Selain itu pemanfaatan pupuk cair MOL lebih murah, ramah lingkungan, dan menjaga keseimbangan alam.

Mikroorganisme Lokal (MOL) yang berupa cairan dapat mempermudah tanaman dalam menyerap unsur hara yang terkandung didalamnya dibandingkan dengan pupuk lainnya yang berbentuk padat. Dalam pengaplikasiannya, selain diberikan melalui tanah yang kemudian diserap oleh akar tanaman. MOL juga dapat diaplikasikan melalui daun tanaman tomat guna mendukung penyerapan unsur hara secara optimal. Hal ini diharapkan dapat memberikan pertumbuhan, hasil, dan mutu tanaman tomat yang lebih baik.

Berdasarkan hasil penelitian Mukhlis, $d k k$ (2012), menyatakan bahwa pemberian MOL sayur-sayuran dan buah-buahan yang paling efektif untuk meningkatkan pertumbuhan tanaman bawang merah pada tanah Alluvial. Sedangkan penelitian Sari $d k k$, (2012) melaporkan bahwa pemberian MOL bonggol pisang berpengaruh nyata terhadap jumlah bunga Rosella (Hibiscus sabdariffa L.) yaitu sebesar 24\% (24 ml/liter air). 
Tujuan penelitian ini adalah untuk mengetahui pengaruh berbagai macam Mikroorganisme Lokal (MOL) terhadap pertumbuhan tanaman tomat (Lycopersicum esculentum Mill) pada tanah ultisol dan untuk mengetahui jenis MOL yang terbaik untuk bisa meningkatkan pertumbuhan tanaman tomat (Lycopersicum esculentum Mill) pada tanah ultisol.

\section{METODE PENELITIAN \\ Tempat dan Waktu penelitian}

Penelitian ini dilaksanakan di Lahan

Percobaan Fakultas Pertanian Universitas Muara Bungo, dengan ketinggian $101 \mathrm{~m}$ diatas permukaan laut, dengan temperatur udara berkisar antara $25^{\circ} \mathrm{C}-31^{\circ} \mathrm{C}$, curah hujan rata-rata per bulan adalah 179-279 mm pada bulan basah dan 68-106 mm pada bulan kering. Penelitian ini dilaksanakan dari tanggal 24 Maret 2017 sampai dengan tanggal 17 Juli 2017.

\section{Bahan dan Alat}

Bahan yang digunakan dalam penelitian ini adalah benih tomat varietas permata, tanah ultisol, pupuk kandang sapi, pupuk NPK mutiara 15:15:15 sebanyak 100 $\mathrm{kg} / \mathrm{ha}$ (2,5 gr/tanaman), Dursban $200 \mathrm{EC}$, bonggol pisang, buah pepaya, pisang, apel, sayur sawi, kangkung, kol, air kelapa, gula merah, air cucian beras, air, dan garam.

Alat yang digunakan dalam penelitian ini adalah polybag ukuran $20 \mathrm{X}$ $30 \mathrm{~cm}$, ember, handsprayer, gembor, botol aqua, jerigen, tali rapia, pisau, parang, saringan, talenan, plastik, naungan dari daun kelapa, koran atau kertas transparan, meteran, timbangan, selang, ajir, gelas ukur, dan alat tulis.

\section{Rancangan Penelitian}

Penelitian ini menggunakan

Rancangan Acak Lengkap (RAL) yang terdiri dari 4 perlakuan yang diulang sebanyak 4 kali sehingga terdapat 16 unit percobaan, Adapun perlakuannya sebagai berikut :

M0 : Tanpa pemberian MOL (Kontrol)

M1 : Pemberian pupuk cair MOL buahbuahan

M2 : Pemberian pupuk cair MOL bonggol pisang

M3 : Pemberian pupuk cair MOL sayursayuran

Setiap unit percobaan terdiri atas 3 tanaman sehingga jumlah keseluruhan tanaman sebanyak 48 tanaman dan semua tanaman dijadikan sampel.

\section{Pelaksanaan Penelitian}

a. Pembuatan Mikroorganisme Lokal (MOL)

\section{MOL Buah-buahan :}

Bahan dan Alat : Limbah Buah-buahan seperti pepaya, pisang, apel, dan lainlain sebanyak $5 \mathrm{~kg}$, air kelapa 3 liter, gula merah 2 ons, pisau, ember, plastik, selang, tali rapia

Cara membuat : Limbah buah-buahan dicincang atau dilumatkan, larutkan gula merah dengan air kelapa, masukkan semua bahan kedalam ember, aduk semua bahan sampai tercampur merata, tutup ember tersebut dan beri lubang untuk aerasi dengan menggunakan selang, fermentasikan selama 2 minggu, dan buka tutup setiap pagi selama lebih kurang 5 menit.

\section{MOL Bonggol Pisang :}

Bahan dan Alat : Bonggol pisang $5 \mathrm{~kg}$, gula merah $1 \mathrm{~kg}$, air beras atau air tawar 10 Liter, ember takaran 15 liter, botol bekas air kemasan $(600 \mathrm{ml})$, selang kecil, parang, koran atau kertas transparan, tali rapia, saring kelapa Cara membuat mol Bonggol pisang : Bongkol pisang di potong-potong menjadi kecil lalu di tumbukkan menjadi halus, masukkan kedalam ember yang telah disediakan, masukkan 
gula merah yang sudah diiris kedalam ember, tambahkan air beras, aduk sampai rata, tutup ember dengan penutupnya atau koranlalu ikatkan dengan rapat-rapat dan berikan selang plastik yang disambung dengan botol kemasan $(600 \mathrm{ml})$ yang diisi air sebanyak $500 \mathrm{ml}$, fermentasi selama 14 - 21 hari, ciri-ciri MOL yang sudah jadi atau siap diaplikasikan, mengeluarkan aroma alkohol berbau tapai.

\section{MOL Sayur-sayuran :}

Bahan dan Alat : Limbah sayuran seperti kangkung $3 \mathrm{~kg}$, sawi $3 \mathrm{~kg}$, kol 4 $\mathrm{kg}$, limbah cucian beras/leri 1 liter, garam $0,5 \mathrm{~kg}$, gula merah 2 0ns, air secukupnya, pisau, talenan, ember/drum plastik, plastik, dan ember

Cara membuat : Limbah sayuran kangkung, sawi, dan kol dipotong kurang lebih $1 \mathrm{~cm}$, masukkan kedalam ember secara berlapis lebih kurang $10 \mathrm{~cm}$, taburkan garam diatasnya, buat secara berlapis tinggi $20 \mathrm{~cm}$ hingga semua bahan potongan sayuran habis digunakan, siram dengan air leri serta air larutan gula merah, tambahkan air hingga $3 / 4$ ember, aduk rata hingga garam dan gula benar-benar melarut, tutup rapat dengan plastik dan ikat erat, setelah 3-4 minggu mol sudah siap untuk digunakan.

\section{b. Persiapan Media Tanam dan Penyemaian}

Tanah di cangkul sedalam $20 \mathrm{~cm}$ dan dibersihkan dari bebatuan, kerikil serta rumput. dibuat bedengan dengan panjang $100 \mathrm{~cm}$ lebar $120 \mathrm{~cm}$ serta tinggi $30 \mathrm{~cm}$. Kemudian diatas bedengan dibuat naungan dari daun kelapa setinggi $150 \mathrm{~cm}$. Sebelum benih disemai, rendam benih dengan air hangat terlebih dahulu selama 15 menit dan pilih benih yang tenggelam. Penyemaian dilakukan dibedengan yang diisi dengan media berupa tanah dan pupuk kandang dengan perbandingan $1: 1$. Setelah itu dibuat lobang tanam dan setiap lobang tanam diisi 2 benih tomat.

\section{c. Penanaman di Polybag}

Komposisi media terdiri dari tanah top soil yang sudah bersih dari kotoran, pasir, dan pupuk kandang dengan perbandingan $3: 1: 1$, kemudian masukkan media sebanyak $5 \mathrm{~kg}$ kedalam masingmasing polybag dan disusun sesuai perlakuan.

Penanaman dilakukan pada bibit yang berumur 17 hari sejak benih disemaikan atau telah memiliki 3-4 helai daun, pemindahan dilakukan dengan cara mencabut tanaman tomat dengan hati-hati tujuannya agar akar tanaman tidak putus, lalu dipindahkan ke polybag. kemudian polybag tersebut disusun dengan jarak $50 \mathrm{x}$ $50 \mathrm{~cm}$ dengan satu unit percobaan dan jarak antar kelompok $60 \mathrm{~cm}$, tujuannya adalah agar lebih mudah dalam pemeliharaan tanaman.

\section{d. Perlakuan}

Pemberian MOL dilakukan setelah tanaman berumur 7 hari setelah tanam dengan cara di semprotkan pada seluruh bagian tanaman. Konsentrasi yang digunakan untuk setiap kali perlakuan untuk masing-masing MOL adalah 24 cc/liter. Penyemprotan dilakukan pada pagi hari antara pukul 08.00-10.00 WIB dengan interval penyemprotan 2 minggu sekali yaitu pada umur 7, 21, 35, 49 dan 63 Hari Setelah Tanam (HST).

\section{e. Pemeliharaan}

Pemeliharaan tanaman meliputi penyiraman, penyulaman, penyiangan, pemupukan, dan pengendalian hama dan penyakit. Penyiraman dilakukan dua kali sehari yaitu pagi dan sore. Penyulaman dilakukan dengan cara mengganti tanaman 
yang mati, penyulaman dilakukan seminggu setelah tanam. Penyiangan dilakukan dengan cara mencabut gulma yang berada didalam polybag. Pemupukan NPK Mutiara (15:15:15) dilakukan pada 30 HST. Pengendalian hama dan penyakit dilakukan dengan penyemprotan insektisida 2 cc per liter Dursban 200 EC untuk membasmi hama ulat buah yang ditemukan pada buah tomat. dilakukan pada saat tanaman berumur 1 minggu setelah tanam, serta pengendalian secara mekanik dengan membuang bagian tanaman yang terserang hama dan penyakit dengan menggunakan tangan.

\section{f. Pemanenan}

Pemanenan tomat dilakukan pada saat buah tomat memasuki stadium matang dengan ciri-ciri sebagian besar permukaan buah sudah berwarna kuning yaitu pada umur \pm 70 hst, kecuali pada panen terakhir yaitu umur \pm 80 hst semua buah yang berwarna hijau juga ikut dipanen.

\section{Variabel Pengamatan}

Variabel pengamatan yaitu : Tinggi tanaman $(\mathrm{cm})$, Diameter batang $(\mathrm{cm})$, Jumlah daun (Helai), Umur berbunga (Hari), dan Umur panen pertama (Hari).

\section{Analisis Data}

Untuk mengetahui pengaruh perlakuan dari variabel yang diamati, maka dilakukan uji statistik dengan mengunakan sidik ragam (anova) apabila berpengaruh nyata maka dilanjutkan dengan uji Ducan Multiple Range Test (DNMRT) pada taraf $5 \%$.

\section{HASIL DAN PEMBAHASAN Tinggi tanaman $(\mathrm{cm})$}

Hasil pengamatan terhadap tinggi tanaman setelah dianalisis sidik ragam menunjukkan bahwa adanya variasi pada tinggi tanaman. Rataan tinggi tanaman tomat pada berbagai macam pemberian MOL dapat dilihat pada Tabel 1 .

Tabel 1. Rataan Tinggi Tanaman Tomat Terhadap Pemberian Berbagai Macam MOL

\begin{tabular}{|l|c|}
\hline \multicolumn{1}{|c|}{ Perlakuan } & $\begin{array}{c}\text { Rata-Rata } \\
(\mathbf{C m})\end{array}$ \\
\hline M0 = Tanpa Pemberian MOL & $60,03 \quad$ b \\
(Kontrol) & \\
M1 = MOL Buah-Buahan & $72,73 \quad$ b \\
M2 = MOL Bonggol Pisang & $99,97 \mathrm{a}$ \\
M3 = MOL Sayur-Sayuran & $79,24 \quad$ b \\
\hline KK = 15,96 \% & \\
\hline Keterangan : Angka-angka yang di ikuti oleh huruf \\
\multicolumn{2}{|c|}{ kecil yang berbeda pada kolom yang } \\
sama menunjukkan berbeda nyata \\
menurut uji DNMRT pada taraf 5\%.
\end{tabular}

Pada Tabel 1. diatas menunjukan bahwa perlakuan M2 berbeda nyata dengan perlakuan M1, M3, dan M0. Hasil tertinggi terdapat pada perlakuan M2 yaitu pemberian MOL bonggol pisang dengan rata-rata tinggi tanaman 99,97 cm. Hal ini diduga MOL bonggol pisang yang diberikan dapat memberikan kontribusi hara yang lebih lengkap yang dibutuhkan oleh tanaman tomat pada tanah ultisol yang miskin unsur hara, sehingga dengan pemberian MOL bonggol pisang berkaitan dengan ketersediaan unsur hara mikro dan makro yang dapat merangsang pertumbuhan tinggi tanaman tomat. Sesuai dengan pernyataan Rukmana (2001), bahwa bonggol pisang mengandung banyak unsur hara diantaranya yaitu air, zat besi, kalsium, karbohidrat, kalori, protein dan fosfor. dan Dwidjoseputro (2005) menyatakan bahwa suatu tanaman akan tumbuh dan berkembang dengan baik apabila unsur hara yang dibutuhkan tanaman berada dalam jumlah yang cukup dan berada dalam bentuk yang siap diabsorbsi. Sedangkan Sutaryat dan Supardiyono (2011) menjelaskan bahwa MOL bonggol pisang mengandung sumber nitrogen dan fosfor bagi tanaman. Dimana 
tanaman memerlukan unsur $\mathrm{N}$ dan $\mathrm{P}$ untuk dapat tumbuh, berkembang dan berproduksi dengan baik dan merangsang pertumbuhan vegetatif.

Selain itu adanya mikroorganisme yang yang terdapat dalam MOL bonggol pisang diduga merangsang proses dekomposisi media, sehingga membantu penyediaan hara dari bahan organik yang tersedia ditanah yang akhirnya dapat meningkatkan penyerapan hara oleh tanaman. Menurut Maspary (2012), dalam mol bonggol pisang mengandung 7 mikroorganisme yang sangat berguna bagi tanaman yaitu : Azospirillium, Azotobacter, Bacillus, Aeromonas, Aspergillus, mikroba pelarut phospat dan mikroba selulotik. Menurut Suiatna (2010) Azospirillium sp merupakan bakteri yang memfiksasi $\mathrm{N}$ di udara yang bersifat non simbiotik. Disamping peranannya secara langsung dalam peningkatan kandungan $\mathrm{N}$ tanaman, Azospirililum sp. juga mampu menghasilkan fitohormon yang dapat merangsang pertumbuhan tanaman antara lain, auksin, gibberellin, dan sitokinin. Haryadi (2005) menjelaskan bahwa gibberellin adalah salah satu golongan ZPT yang berfungsi merangsang pembelahan sel, pemanjangan sel, dan fungsi pengatur tinggi tanaman.

Pada perlakuan M0, M1 dan M3 masing-masing perlakuan tidak berbeda nyata, dengan rata-rata tinggi tanaman yaitu $60,03 \mathrm{~cm}, 72,73 \mathrm{~cm}$ dan 79,24 cm. Hal ini diduga unsur hara yang terdapat pada masing-masing MOL belum mencukupi kebutuhan pertumbuhan tanaman tomat pada tanah ultisol, sehingga pertumbuhan tanaman tomat diperoleh dari unsur hara yang ada pada media tanam saja. Media tanam yang dipakai adalah campuran dari tanah, pasir dengan pupuk kadang dengan perbandigan $3: 1: 1$.

Dinamika pertumbuhan tinggi tanaman tomat pada pengamatan interval 2 minggu sekali dari umur 14 sampai 56 hari setelah tanam dengan perlakuan pemberian berbagai macam Mikroorganisme Lokal (MOL) disajikan dalam bentuk Gambar 1 berikut :

Gambar1. Grafik Tinggi Tanaman Umur 1456 hari setelah tanam (hst)

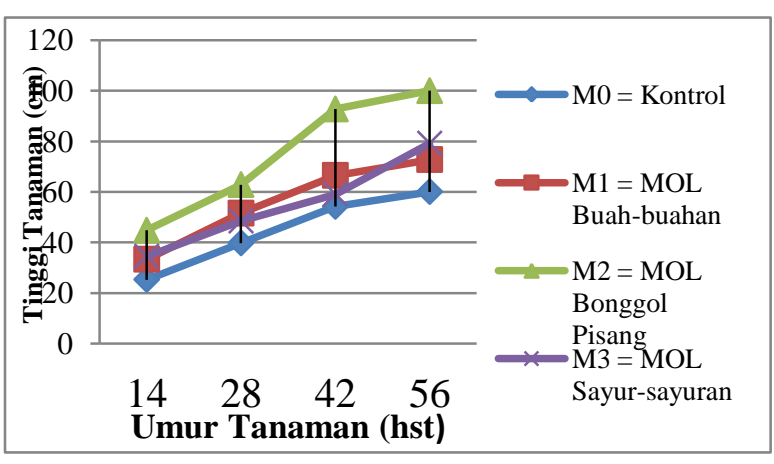

Dari gambar 1 diatas terlihat jelas bahwa masing-masing perlakuan berbagai macam MOL pada tanaman tomat terjadi peningkatan tinggi tanaman pada setiap minggunya. Pada awal pengamatan umur tanaman 14 hst pemberian berbagai macam MOL sudah mulai bereaksi dan mulai dapat dimanfaatkan oleh tanaman sehingga dapat meningkatkan tinggi tanaman meskipun berbagai MOL belum dapat menunjukkan keunggulan masing-masing hal ini terlihat dari grafik dimana perlakuan M1 dan M3 masih menunjukkan pertumbuhan tinggi tanaman yang sama.

Berbagai macam MOL bereaksi sepenuhnya dan dapat dimanfaatkan oleh tanaman pada umur 28-56 hst dimana pemberian berbagai MOL mulai memperlihatkan keunggulan masingmasing. Pada gambar 1 terlihat jelas bahwa berbeda perlakuan berbeda pula tinggi tanaman tomat yang dihasilkan. Perlakuan M2 menghasilkan tinggi tanaman tertinggi dan grafik menunjukkan pengaruh perlakuan M2 pada tanaman tomat sudah memperlihatkan reaksi penuh dari umur tanaman 14 hst terus mengalami pertumbuhan tanpa mengalami hambatan sampai pada umur 56 hst. Sedangkan perlakuan M1, M3 dan M0 menghasilkan 
tinggi tanaman tomat yang tidak jauh berbeda.

\section{Diameter Batang (cm)}

Berdasarkan hasil analisis ragam menunjukkan bahwa pemberian berbagai macam MOL berpengaruh tidak nyata terhadap Diameter Batang. Rataan Diameter Batang $(\mathrm{cm})$ tanaman tomat pada pemberian berbagai macam MOL dapat dilihat pada Tabel 2.

Tabel 2. Rataan Diameter Tanaman Tomat Terhadap Pemberian Berbagai Macam MOL

\begin{tabular}{|l|c|}
\hline \multicolumn{1}{|c|}{ Perlakuan } & $\begin{array}{c}\text { Rata-Rata } \\
(\mathbf{C m})\end{array}$ \\
\hline M0 $=$ Tanpa Pemberian MOL & 2,58 \\
(Kontrol) & \\
M1 = MOL Buah-Buahan & 2,63 \\
M3 $=$ MOL Bonggol Pisang & 2,92 \\
\hline KK $=$ 9,75 \% & 2,63 \\
\hline
\end{tabular}

Keterangan : Perlakuan tidak berbeda nyata terhadap diameter batang $(\mathrm{cm})(\mathrm{P}>0,05)$.

Tabel 2 menunjukkan bahwa berbagai macam MOL berpengaruh tidak nyata terhadap diameter batang tanaman tomat. Hal ini diduga unsur hara yang terkandung pada berbagai macam MOL yang diberikan tidak dapat dimanfaatkan sepenuhnya untuk peningkatan diameter batang dan diduga faktor lingkungan lebih dominan terhadap diameter batang seperti intensitas sinar matahari. Dalam hubungan antara cahaya matahari dengan tanaman, selalu terdapat keterkaitan antara sinar matahari dan proses fotosintesis. Fotosintesis merupakan proses pembuatan makanan yang terjadi pada tumbuhan hijau dengan bantuan sinar matahari dan enzimenzim. Hasil fotosintesis digunakan untuk mendukung pertumbuhan dan perkembangan tanaman.

Menurut Jumin (2005), batang merupakan daerah akumulasi pertumbuhan tanaman khususnya pada tanaman yang lebih muda sehingga dengan adanya unsur hara yang dapat mendorong pertumbuhan vegetatif tanaman diantaranya pembentukan klorofil pada daun sehingga akan memacu laju fotosintesis. Semakin laju fotosintesis maka fotosintat yang dihasilkan akan memberikan ukuran pertambahan lingkar batang yang besar. Marjenah (2001) menyatakan bahwa pertumbuhan diameter batang lebih cepat pada tempat terbuka dari pada tempat ternaung sehingga tanaman yang ditanam pada tempat terbuka cenderung pendek dan kekar sedangkan Simonangkir (2000) menyatakan bahwa pertumbuhan diameter tanaman berhubungan erat dengan laju fotosintesis yang akan sebanding dengan jumlah intensitas cahaya matahari yang diterima dan respirasi.

\section{Jumlah Daun (helai)}

Hasil pengamatan terhadap jumlah daun setelah dianalisis sidik ragam menunjukkan adanya variasi pada jumlah daun. Rataan jumlah daun tanaman tomat pada berbagai macam pemberian MOL dapat dilihat pada Tabel 3.

Tabel 3. Rataan Jumlah Daun (helai) Tanaman Tomat Pada Pemberian Berbagai Macam MOL.

\begin{tabular}{|c|c|}
\hline Perlakuan & $\begin{array}{c}\text { Rata-Rata } \\
(\mathbf{C m})\end{array}$ \\
\hline $\begin{aligned} \mathrm{M} 0= & \text { Tanpa Pemberian } \mathrm{MOL} \\
& (\text { Kontrol })\end{aligned}$ & $59,00 \quad b$ \\
\hline M1 = MOL Buah-Buahan & 73,75 \\
\hline M2 = MOL Bonggol Pisang & $143,37 \mathrm{a}$ \\
\hline M3 = MOL Sayur-Sayuran & $79,87 \quad b$ \\
\hline $\mathrm{KK}=21,88 \%$ & \\
\hline
\end{tabular}

Keterangan : Angka-angka yang di ikuti oleh huruf kecil yang berbeda pada kolom yang sama menunjukkan berbeda nyata menurut uji DNMRT pada taraf 5\%.

$\begin{array}{ccrc}\text { Tabel } & 3 & \text { menunjukan } & \text { bahwa } \\ \text { perlakuan } & \text { berbagai macam } & \text { MOL }\end{array}$


berpengaruh nyata terhadap jumlah daun (helai) tanaman tomat. Perlakuan M2 berbeda nyata dengan perlakuan M1, M3, dan M0. Jumlah daun paling banyak ditemukan pada perlakuan M2 yaitu 143,37 helai dan paling sedikit pada perlakuan M0 yaitu 59,00 helai. Hal ini berhubungan dengan ketersediaan unsur hara yang mudah terserap dan segera dapat digunakan oleh tanaman khususnya dalam hal pembentukan daun. Karena daun merupakan organ vegetatif tanaman yang menjadi pusat pembuatan makanan pada suatu tumbuhan maka membutuhkan asupan yang dapat membantu proses perkembangan organ vegetatif tersebut seperti unsur hara mikro dan makro, yang paling vital yaitu unsur Nitrogen $(\mathrm{N})$. Hal ini selaras dengan unsur yang terdapat pada bonggol pisang yaitu nitrogen. Sesuai dengan hasil penelitian Kusumawati (2015), yang menyatakan bahwa bonggol pisang merupakan salah satu bahan pembuatan pupuk organik cair yang mengandung $\mathrm{N}+\mathrm{P} 2 \mathrm{O} 5+\mathrm{K} 2 \mathrm{O}$ sebanyak $7,74 \%$. Unsur Nitrogen didalam bonggol pisang inilah yang dapat menjadi pendukung proses pertumbuhan tanaman khususnya pada jumlah helai daun.

Kandungan hara $\mathrm{N}$ yang terdapat dalam MOL bonggol pisang ini dapat dimanfaatkan secara optimal oleh tanaman sehingga proses fotosintesis didaun meningkat. Hasil dari fotosintesis tersebut kemudian ditranslokasikan keseluruh bagian tanaman untuk pertumbuhan dan perkembangan tanaman. Menurut Wijaya, (2010) menyatakan penambahan nitrogen pada tanaman dapat mendorong pertumbuhan organ-organ yang berkaitan dengan fotosintesis seperti daun. Tanaman yang cukup mendapat suplai nitrogen akan membentuk daun yang memiliki helaian lebih luas dengan kandungan klorofil yang lebih tinggi, sehingga tanaman mampu menghasilkan karbohidrat/asimilat dalam jumlah yang tinggi untuk menopang pertumbuhan vegetatif

\section{Umur Berbunga (hari)}

Berdasarkan hasil analisis ragam menunjukkan bahwa pemberian berbagai macam MOL berpengaruh tidak nyata terhadap umur berbunga. Rataan umur berbunga (hari) tanaman tomat pada pemberian berbagai macam MOL dapat dilihat pada Tabel 4.

Tabel 4. Rataan umur berbunga (hari) Tanaman Tomat Pada Pemberian Berbagai Macam MOL

\begin{tabular}{|l|c|}
\hline \multicolumn{1}{|c|}{ Perlakuan } & $\begin{array}{c}\text { Rata-Rata } \\
(\mathbf{C m})\end{array}$ \\
\hline M0 = Tanpa Pemberian MOL & 26,50 \\
(Kontrol) & \\
M1 = MOL Buah-Buahan & 26,75 \\
M2 = MOL Bonggol Pisang & 26,34 \\
M3 = MOL Sayur-Sayuran & 26,34 \\
\hline KK = 3,17 \% & \\
\hline
\end{tabular}

Keterangan : Perlakuan tidak berbeda nyata terhadap umur berbunga (Hari) $(\mathrm{P}>0,05)$.

Tabel 4. menunjukkan bahwa berbagai macam MOL berpengaruh tidak nyata terhadap umur berbunga tanaman tomat. Hal ini diduga bahwa pemberian berbagai macam MOL melalui daun tidak dapat dimanfaatkan oleh tanaman secara optimal terutama unsur hara $\mathrm{P}$ dan $\mathrm{K}$ sehingga pertumbuhan generatif tanaman terhambat sehingga perlakuan tidak menunjukan pengaruh nyata terhadap umur mulai berbunga.

Menurut Purbayanti, et al., (1995) dalam Fahrudin (2009) kekurangan unsur P menyebabkan pertumbuhan sel tanaman akan tertunda sehingga proses penyerbukan tidak terjadi, pertumbuhan sel menjadi kerdil karena pembelahan sel terganggu, terjadi klorosis dan bentuk buah tidak normal. Apabila fospor dalam tanah tidak tersedia bagi tanaman pada awal pertumbuhan akan 
terhambatnya pertumbuhan generatif tanaman.

Menurut Dwidjoseputro (2005) menyatakan bahwa unsur Kalium berfungsi dalam membantu pembentukan protein juga dalam penyusunan dan pembongkaran Karbohidrat, kekurangan Kalium dapat berakibat terhambatnya fotosintesis dan pertumbuhan bunga atau buah. Hal ini diduga unsur hara yang terkandung pada berbagai macam MOL yang diberikan tidak dapat dimanfaatkan sepenuhnya untuk peningkatan umur berbunga tanaman tomat.

\section{Umur Panen Pertama (hari)}

Hasil analisis ragam menunjukkan bahwa berbagai macam MOL berpengaruh nyata terhadap umur panen pertama. Rataan umur panen pertama (Hari) tanaman tomat pada pemberian berbagai macam MOL dapat dilihat pada Tabel 5.

Tabel 5. Rataan Umur Panen Pertama (Hari)

Tanaman Tomat Pada Pemberian

Berbagai Macam MOL.

\begin{tabular}{|c|c|}
\hline Perlakuan & $\begin{array}{c}\text { Rata-Rata } \\
\text { (Cm) }\end{array}$ \\
\hline $\begin{aligned} \text { M0 }= & \text { Tanpa Pemberian MOL } \\
& (\text { Kontrol })\end{aligned}$ & 82,34 a \\
\hline M1 = MOL Buah-Buahan & $78,67 \mathrm{ab}$ \\
\hline M2 = MOL Bonggol Pisang & $75,71 \quad b$ \\
\hline M3 = MOL Sayur-Sayuran & $78,84 \mathrm{ab}$ \\
\hline $\mathrm{KK}=3,37 \%$ & \\
\hline
\end{tabular}

Keterangan : Angka-angka yang di ikuti oleh huruf kecil yang berbeda pada kolom yang sama menunjukkan berbeda nyata menurut uji DNMRT pada taraf 5\%.

Tabel 5 menunjukan bahwa perlakuan berbagai macam MOL berpengaruh nyata terhadap umur panen pertama pada tanaman tomat. Perlakuan M0 tidak berbeda nyata dengan perlakuan M1 dan M3 tetapi berbeda nyata dengan perlakuan M2. Hal ini diduga bahwa pengaruh berbagai macam MOL dapat memenuhi kebutuhan tanaman akan unsur hara $\mathrm{N}, \mathrm{P}$ dan $\mathrm{K}$ selain unsur hara lainnya yang terkandung dalam berbagai macam MOL.

Setyamidjaja (1986), Menyatakan bahwa $\mathrm{N}$ berperan dalam mempercepat pengubahan karbohidrat menjadi protein yang berpengaruh pada pembelahan, pemanjangan, dan pembesaran sel baru sehingga mempercepat pembuahan. Selain unsur hara nitrogen didalam tanah juga terdapat unsur hara pospor, kalium, magnesium dan unsur hara mikro. Sutedjo (2008) menyatakan bahwa tanaman menyerap unsur hara pospor dalam bentuk $\mathrm{H}_{2} \mathrm{PO}^{-4}$, dan $\mathrm{HPO}^{-4}$. fungsi dari unsur hara pospor tersebut adalah untuk mempercepat pertumbuhan akar semai, memperkuat pertumbuhan tanaman muda menjadi tanaman dewasa, mempercepat pemasakan buah dan biji atau gabah serta dapat meningkatkan biji-bijian.

Perlakuan M2 merupakan perlakuan yang terbaik untuk umur panen pertama pada tanaman tomat karena pada perlakuan M2 dapat mempercepat waktu panen tanaman tomat yaitu dengan rataan sebesar 75,71 hari. Hal ini disebabkan karena unsur hara makro dan mikro, serta adanya mikroorganisme yang terkandung dalam MOL bonggol pisang dapat dimanfaatkan secara optimal oleh tanaman tomat pada tanah ultisol. Sehingga kemampuan tanaman menyerap unsur hara menjadi lebih baik. Budiyani et al., (2016), menyatakan bahwa mikroorganisme yang terdapat pada MOL bonggol pisang antara lain jenis Bacillus sp., Aeromonas sp., Azospirillium sp., Azotobacter sp., Aspergillus nigger dan mikroba selulolitik. Mikroba inilah yang biasa menguraikan bahan organik dan dapat membantu pertumbuhan pada tanaman. Arum, et al., (2013), melaporkan bahwa Aspergillus nigger merupakan kelompok fungi pelarut fosfat. Selain itu Aspergilus niger juga berpotensi menghasilkan enzim selulasa yang berfungsi untuk mendegradasi selulosa. Jamur ini mempunyai kemampuan 
lebih tinggi dalam melarut fosfat terikat dibandingkan bakteri. Hasil penelitian Imaningsih dan Anas (1996) et al., Suhastyo, 2011 menyatakan bahwa Aspergillus niger dapat meningkatkan kelarutan fosfat dari AlPO4 sebesar 13,5\% dan dapat meningkatkan fosfat larut dalam tanah Ultisol 30,4\% dibanding kontrol.

\section{KESIMPULAN DAN SARAN}

\section{Kesimpulan}

1. Berbagai macam MOL berbeda nyata terhadap tinggi tanaman $(\mathrm{cm})$, jumlah daun (helai), umur panen pertama (hari) serta tidak berbeda nyata terhadap diameter batang $(\mathrm{cm})$, dan umur mulai berbunga (hari)

2. Perlakuan M2 (MOL bonggol pisang) merupakan perlakuan terbaik untuk meningkatkan pertumbuhan tanaman tomat (Lycopersicum esculentum Mill) pada tanah ultisol.

\section{Saran}

Untuk meningkatkan pertumbuhan tanaman tomat disarankan untuk menggunakan mikroorganisme lokal (MOL) bonggol pisang dan disarankan untuk melakukan penelitian lebih lanjut pada tanaman yang berbeda, dengan lama fermentasi MOL yang berbeda dan konsentrasi penyemprotan yang berbeda.

\section{DAFTAR PUSTAKA}

Arum, A, S. Iswadi, A. Dwi, A.S. dan Yulin, L. 2013. Studi Mikrobiologi dan Sifat Kimia Mikroorganisme Local (MOL) Yang Digunakan Pada Budidaya Padi Metode SRI (System of Rice Intensification). Jurnal Sainteks Fakultas MIPA Institut Pertanian Bogor. Bogor. 10 (2) : 2940.
BPS Provinsi Jambi, 2014. Produksi Sayuran dan Buah-buahan.

Budiyani, N.K,. Soniari, N.N., \& Sutari, N.W.S. (2016). ^ 1isis Kualitas Larutan Mikr ne Lokal (MOL) Bonggo, ‘g. E-Jurnal Agroekoteknologi 'Iropika, 5 (1), 63-72.

Dwidjoseputro, 2005. Pengantar Fisiologi Tumbuhan. Gramedia Pustaka Utama. Jakarta.

Fahrudin, F. 2009. Budidaya Caisin (Brassica juncea L.) Menggunakan Ekstrak The dan Pupuk Kascing. Skripsi Fakultas Pertanian. Universitas Sebelas Maret. Surakarta.

Hanafiah, K. A. 2005. Dasar-dasar Ilmu Tanah. PT. Raja Grafindo Persada. Jakarta. 360 hal.

Haryadi, S.S.M.M. 2005. Pengantar Agronomi. Gramedia Pustaka Utama. Jakarta.

Jumin, H.B. 2005. Ekologi Tanaman Suatu Pendekatan Fis: Rajawali Press. Jakarta.

Kusumawati, A. (2015). Analisa Karakteristik Pupuk Kompos Berbahan Batang Pisang. ISBN 978602-73690-3-0. 323-329. (Seminar Nasional Universitas PGRI Yogyakarta 2015).

Marjenah, 2001. Penyebaran Pohon Manglid (Manglietia glauca) di Kawasan Hutan Lindung Gunung Salak. Laporan Ekspedisi Manglid. www. Rimpala.Com. Bogor 
Maspary. 2012. Apa Kehebatan MOL Bonggol Pisang. http://www.gerbangpertanian.com/20 12/05/apa-kehebatan-mol-bonggolpisang.html

Mukhlis, Purwaningsih, Anggorowati.D. 2012. Pengaruh berbagai jenis mikroorganisme lokal (MOL) terhadap pertumbuhan dan hasil Bawang Merah pada tanah Alluvial. Artikel ilmiah. Jurusan Budidaya pertanian. Universitas Tanjungpura Pontianak.

Prahastuti, S. W. 2005. Perubahan Beberapa Sifat Kimia dan Serapan P Jagung Akibat Pemberian Bahan Organik dan Batuan Fosfat Alam pada Ultisol Jasinga Jurnal Agroland : 12:(1).

Purwasasmita, M. 2009b. Mikroorganisme Lokal Sebagai Pemicu Siklus Kehidupan Dalam Bioreaktor Tanaman. Seminar Nasional Teknik Kimia Indonesia, 19 - 20 Oktober 2010.

Rukmana, R. (2001). Aneka Olahan Limbah: Tanaman Pisang, Jambu Mete, Rossela. Yogyakarta: Kanisius.

Sari,N.D, Kurniasih S. dan Rostikawati, T.R. 2012. Pengaruh pemberian Mikroorganisme Lokal (MOL) Bonggol Pisang Nangka terhadap produksi Rosella (Hibiscus Sabarifal). Program studi pendidikan Biologi Fakultas Keguruan dan ilmu pendidikan. Universitas Pakuan.

Setyamidjaja, D, 1986. Pupuk dan Pemupukan.Simplex. Jakarta.
Simonangkir, B.D.A.S. 2000. Analisis Riap Dryobalanops Ianceolata Burc pada Lebar Jalur yang Berbeda di Hutan Koleksi Universitas Mulawarman Lempake. Frontir Nomor 32. Kalimantan Timur.

Suhastyo. A. A, 2011. Studi Mikrobiologi dan Sifat Kimia Mikroorganisme Lokal (Mol) yang digunakan pada Budidaya Padi Metode Sri ( System Of Rice Intensification )

Suiatna, R,U., 2010. Bertani Padi Organik Pola Tanam Sri. Penerbit Padi Bandung. Bandung

Suprapto. H. S. 2000. Bertanam Sayuran Buah. Penebar Swadaya. Jakarta.

Supriyati, Y dan Siregar, D, 2009. Bertanam Tomat dalam Pot dan Polibag. Penebar Swadaya. Jakarta.

Sutaryat, A dan S. Suparyono. 2011. Sumber hara. Trubus.

Syaifudin, A., L. Mulyani., dan E. Sulastri. $2010 . \quad$ Pemberdayaan MikroOrganisme Lokal Sebagai Upaya Peningkatan Kemandirian Petani. Karya Tulis.

Wijaya. A.R. 2010. Pupuk dan Pemupukan. Kanisius.Yogjakarta. 
